\title{
SØNDERJYDSKE \\ AARBØGER
}

I. Halvbind

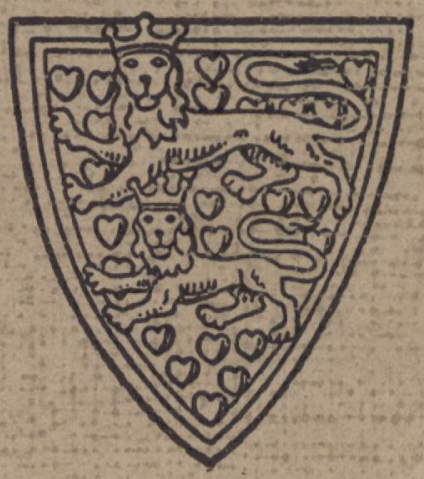

1947

Udgivet af

Historisk Samfund for Sonderiylland 


\section{AKTIESELSKABET}

\section{NORDISKE KABEL- OG TRAADFABRIKER}

K Ø B EN H VN F.

\ INGEN ANSEARLIG DANSEER ....

maa væare uden Kendskab fil dette historiske Dokument, der med lysende Klarhed og realistisk Objektivitet redeger for Forhistorien til den Epoke vi nu gaar ind $\mathrm{i}$. Det er de sidste 15 Aars Historie $i$ en Nøddeskal.

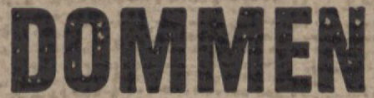

i Nürnberg

Den danske Udgave der er oversat direkte efter wwarcrimes executiveks stonografiske Referat, - saavidt vides - den forste fuldstæendige Offentliggørelse i Bogform i Europa.

Med Forord af Prof. Dr, jur. Stephan Hurwitz $\mathrm{Kr}, 9,50$.

\section{GJ ELEETUP}

\section{A. R. K i a r b ye Sønderjydsk Tæppefabrik Hojer}

Fabrikation afs

Afp. Gulvtæpper med Bort, Tæppetøj til Sammensyning, Lobere. Faas i alle førende Tæppe- og Manufakturforretninger.

\section{Stot de sanderjydske Indsamlinger!}

Kontoret for Annoncers GI. Kongevej 156, Kobenhavn V. Teleton Vester 7823 